\title{
CROSS-FOSTERING BETWEEN TWO SPECIES OF MARMOSETS (Callithrix jacchus AND Callithrix penicillata)
}

\author{
GUERRA, R. F., TAKASE, E. and SANTOS, C. V. \\ Núcleo de Estudos Comportamentais de Primatas, Laboratório de Psicologia Experimental, \\ Departamento de Psicologia, UFSC, CEP 88040-900, Florianópolis, SC, Brazil \\ Correspondence to: Rogerio F. Guerra, Núcleo de Estudos Comportamentais de Primatas, Laboratório de \\ Psicologia Experimental, Departamento de Psicologia, UFSC, CEP 88040-900, Florianópolis, SC, Brazil, \\ e-mail: rfguerra@cfh.ufsc.br \\ Received March 19 ${ }^{\text {th }}, 1998$ - Accepted September 14 ${ }^{\text {th }}, 1998$ - Distributed November 30, 1998
}

(With 1 figure)

\begin{abstract}
Cross-fostering technique can be defined as adoption of infants by adults of other species. This phenomenon is poorly investigated because very young animals have few opportunities to interact peacefully with non-conspecific adults, either in captivity or in natural conditions. This study describes the induction of cross-fostering in captivity between white tufted-ear (Callithrix jacchus) and black tuftedear marmosets (Callithrix penicillata). We conclude that this technique can be very useful for preserving the life of rejected by parents or orphan infants, mainly in the case of species with low reproduction rate in captivity or those threatened by extinction, as well for investigating the environmental effects on the typical behavior of species (courtship, food preference, vocalization patterns, e.g.).
\end{abstract}

Key words: Cross-fostering, parental behavior, infants, reproduction in captivity, marmosets.

\section{RESUMO}

\section{Cross-fostering entre duas espécies de sagüis (Callithrix jacchus e Callithrix penicillata)}

Cross-fostering pode ser definido como a adoção de filhotes por indivíduos adultos de outra espécie. Este fenômeno é pouco estudado, pois filhotes muito jovens dificilmente têm a oportunidade de interagir pacificamente com indivíduos não-conspecíficos adultos, tanto em cativeiro como em condições naturais. Neste estudo, é descrita a indução de dois episódios de cross-fostering entre os sagüis de tufo branco (Callithrix jacchus) e de tufo preto (Callithrix penicillata) em cativeiro. Foi constatado que este procedimento é viável e ele pode ser útil para preservar a vida de filhotes rejeitados pelos pais ou órfãos, especialmente no caso de espécies com baixa taxa de reprodução em cativeiro ou espécies ameaçadas de extinção. Além disso, o cross-fostering pode ser usado para verificar a influência ambiental sobre o comportamento típico da espécie (cortejamento, preferência alimentar, padrões de vocalizações, por exemplo).

Palavras-chave: Cross-fostering, comportamento parental, filhotes, reprodução em cativeiro, sagüis.

\section{INTRODUCTION}

The infant primate is extremely dependent on parental care. The literature reveals that adults can exhibit several types of alloparental behavior toward infants (Hrdy, 1976; Riedman, 1982). In fact, mothers have few infants during their life, they mate very late, the gestation period is very long and the costs of rearing infants are very high. All these factors make the loss of young animals extremely disadvantageous for the mothers (Lancaster, 1971; Leutenegger, 1979). It has been suggested that allomaternal care can be very useful for the mothers, because they can reduce the expenditure of time and energy dedicated to rearing their infants, and the allomothers have an opportunity for motherhood training (Guerra, 1989; Fairbanks, 1990; Gould, 1992). 
However, some previous studies have demonstrated that adoptions and kidnappings may be dangerous for the infants since they can die from starvation if the allomother is a non-lactating female (Hrdy, 1976; Quiatt, 1979; Shopland \& Altmann, 1987).

In Callitrichids, the rejection of infants is not uncommon and can be associated with disturbances in the family structure, the motherhood inexperience or the incidence of triplet births (Johnson et al., 1979; Snowdon, 1996). In order to preserve the life of orphans and rejected by parents young animals (Pook, 1976; Meder, 1989; Boere \& Fernandez, 1993), as well as to rear the animals to be used in immunological investigations (Wolfe et al., 1972), hand-rearing technique has been used with reasonable success. Furthermore, Hearn and Burden (1979) demonstrated that all three of triplet infants $C$. jacchus can survive by alternating the short-term period of maternal care deprivation - i.e., one infant was removed from the mother at a time and placed in pediatric incubator with a surrogate mother for 24 hours.

On the other hand, cross-fostering - the adoption of infants by non-conspecific adults is a phenomenon poorly investigated because very young animals have few opportunities to interact peacefully with adults of other species, either in natural conditions or captivity. However, it has already been demonstrated that cross-fostering may be induced in rodents (Denenberg et al., 1964; McGuire \& Novak, 1987) and some primate species (Owren \& Dieter, 1989; Owren et al., 1993; Smith, 1986).

The main purpose of this article is to describe two episodes of cross-fostering between white tufted-ear (C. jacchus) and black tufted-ear marmosets ( $C$. penicillata), showing that this technique can be used for preserving the life of immature animals or for investigating the environmental effects on the behavior of species.

\section{HOUSING AND HANDLING}

The animals were housed in large outdoor wire mesh home cages $(0.8 \mathrm{~m}$ wide $\mathrm{x} 1.65 \mathrm{~m}$ high $\mathrm{x} 1.4 \mathrm{~m}$ deep) with branches of tree and wood refuge inside $(50 \mathrm{~cm}$ wide $\times 20 \mathrm{~cm}$ high $\mathrm{x} 20 \mathrm{~cm}$ deep). The wire mesh roof of home cages was partially covered with tiles of amianthus, allow- ing the natural illumination and the animals' protection against the rain. The animals belonged to the colony of Callitrichids at the Núcleo de Estudos Comportamentais de Primatas (NUCLEP/ UFSC). They were fed twice a day with a diet of fruits (orange, papaya, apple, melon, banana etc), integral bread, powdered milk, chicken eggs, tenebrio larvae, and vitamin supplements.

\section{DESCRIPTIONS OF EPISODES}

\section{Episode 1 - Male infant $C$. penicillata reared by adults $C$. jacchus}

It was noted that a primiparous female $C$. penicillata exhibited low level of maternal responsiveness immediately after the birth of its infant twins (December 19/1996); one infant was born dead and the other was rejected by the mother and exhibited distressful vocalizations and a visible physical weakness on the second day after the birth. As it was concluded that he could not survive for a long time in those conditions, he was removed from the maternal cage and placed with a couple of $C$. jacchus. Although Callitrichids usually give birth to twins, this couple had given birth to a single infant 32 days before (November 17/1996). Initially, the infant $C$. penicillata was placed on the floor of the $C$. jacchus home cage. Few minutes after, the adult male approached slowly, touched and embraced the infant. The infant held on the male's ventral surface and he was immediately transported to the upper places of the home cage in a ventroventral way. In the following days, it has been noted that the male and female adults alternated the alloparental care (time spent in bodily interactions, allogrooming and transporting infant, e.g.), as they did with their own infant. Approximately 150 days after this, the cross-fostering seemed to have been successful since the infant C. penicillata did not exhibited distressful vocalizations and there were no other signs indicating rejection (skin lesions, decreased locomotor activity or low level of bodily interactions with adults or infant $C$. jacchus, e.g.). On the other hand, it has been noted that the cross-fostered infant exhibited clear difficulties in body weight gain. This was probably due to the advanced lactation stage of the adult female $C$. jacchus whose parturition 32 days before the cross-fostering might have caused a decreased milk supply to the 
cross-fostered infant and/or due to the difference between the milk composition of species. The cross-fostering did not impair the sexual relationship between the male and the female $C$. jacchus since they copulated normally and female gave birth to another single infant (May 24/1997). At the parturition, the cross-fostered infant had 156 days of age and it has been noted that he spent a large amount of time in bodily interactions with mother and their newborn infant. Sometimes he helped his allomother in transporting the newborn without any visible distressful reactions of the parents.

\section{Episode 2 - Male infant $C$. jacchus reared by adults $C$. penicillata}

In the dawn of February 6/1997, the colony of Callitrichids at the NUCLEP/UFSC was invaded by the Animal Liberation Front/SC $C^{1}$. Approximately 80 animals were released by the invaders and many families (male, female and their infants) or recently formed male-female pairs were suddenly separated. Most of the animals were recaptured in the same day, but the parents of some infants were not identified. The invasion caused a serious problem for the NUCLEP/ UFSC's staff because many animals were either newborn or very young and could not survive without parental care. In an attempt to preserve their lives, an infant $C$. jacchus of approximately 75-90 days of age was recaptured and placed in the home cage of a couple $C$. penicillata in the following day after the invasion (February 7/ 1997). The female $C$. penicillata was nulliparous, but her motherhood inexperience was not considered to be a serious problem because the infant was not very young. Due to the operational problems caused by the invaders, the interaction between the couple and the cross-fostered infant could not be measured in the first days after this procedures, but further systematic observations did not indicate the rejection of infant (distressful vocalizations, abnormal jumping activity, facial expressions of fear, e.g.).

Thereafter, it has been noted that the social interactions and some affiliative behavior between animals (allogrooming, time spent in bodily interactions, resting together, e.g.) increased gradually as a function of time. As described in episode 1 , it has been noted that the sexual relationship between the male and the female $C$. penicillata was not impaired since they copulated and the female gave birth to twins six months later (August 31/1997).

Soon after parturition, it has been noted that the cross-fostered infant spent most time in bodily interactions with the couple of $C$. penicillata. Sometimes he even helped his allomother in transporting her newborn infants without distressful reactions or some objections of the parents. In all phases of this cross-fostering episode, it has been noted that the infant $C$. jacchus did not exhibit distressful vocalization, their physical development (body weight gain and locomotor activity, e.g.) was not impaired and no skin lesions were noted on their body (see Fig. 1), which indicate that these cross-fostering procedures were more successful than the procedures described in the previous episode.

\section{DISCUSSION}

In many species of primates the adults exhibit some interest in immature animals which can contribute to the survival of the species since orphans or very young animals rejected by parents can be adopted by adults of their social group (Hrdy, 1976; Quiatt, 1979; McKenna, 1979; Riedman, 1982). Some previous studies have shown that adoption can occur in primates (Hamilton et al., 1982; Thiery \& Anderson, 1986; Blersh \& Schmidt, 1992; Ellsworth \& Andersen, 1997). On the other hand, cross-fostering has been rarely investigated since very young animals have few opportunities for peaceful interaction with non-conspecific adults, either in natural conditions or in captivity.

While some studies revealed that cross-fostering can be induced in rodents (Denenberg et al., 1964; Huck \& Banks, 1980; McGuire \& Novak, 1987; McGuire, 1988), few studies have been carried out with primates. However, it has been demonstrated that this technique can be used to measure the environmental effects on the development of vocalization in rhesus (Macaca mulatta) and Japanese monkey (M. fuscata) infants (Owren et al., 1993). Our results indicate that cross-fostering can be induced in Callitrichids, showing that parental behavior of $C$. jacchus and $C$. penicillata is not very different or incompatible. In fact, crossfostering can be an useful tool to improve the breeding performance of colony of Callitrichids, 
because the life of orphans or the infants rejected by their parents can be preserved. However, our results indicate that the physical development of cross-fostered infants should be monitored continuously in order to prevent decreased body weight gain, as observed in episode 1, or to prevent the rejection of the infant. White tufted-ear and black tufted-ear marmosets inhabit different areas in Brazil and these species exhibit some behavioral and morphological differences (Mittermeier \& CoimbraFilho, 1981), but it has been noted that adult females exhibited some interest and displayed maternal care toward the cross-fostered infant.

On the other hand, the difficulties with body weight gain by the infant $C$. penicillata could be due to the advanced lactation stage (i.e., decreased milk supply) of $C$. jacchus female and/or due to differences in the milk composition of these two species. In fact, Owren \& Dieter (1989) have shown that cross-fostering between $M$. mulatta and $M$. fuscata can be induced and that the infants do not need an intense medical treatment, but the results indicated that $M$. mulatta infants gain body weight faster than $M$. fuscata infants, presumably due to the differences in the maternal milk composition of these two species.

In summary, our results indicate that crossfostering technique can be a very useful tool to preserve the life of orphans or very young animals rejected by parents, mainly in species with low reproduction rate in captivity or threatened by extinction. However, it is important to point out that cross-fostering should be made between related species and that very young animals should be placed with a lactating female in order to prevent starvation or decreased body weight gain. Despite these restrictions, it appears that cross-fostering is better than hand-rearing technique because infants are not deprived of social interaction and receive basic somatosensorial stimulation (warmth by bodily interactions, transport, nursing, allogrooming, e.g.). Furthermore, cross-fostering technique can be used for investigating the environmental effects on the development of some behavioral patterns of species, such as vocalizations, food preferences, courtship and facial expressions.

Acknowledgments - This research was supported by CNPq (Projeto Integrado de Pesquisa 524309/96.5, to R.F. Guerra) and CAPES (predoctoral fellowship, to C.V. Santos). NUCLEP/UFSC is in accordance with the Brazilian legislation on animal captivity (IBAMA 1/42/93/0641-3).

Note $-{ }^{1}$ In the dawn of February 6/1997, the colony of Callitrichids at the NUCLEP/UFSC was invaded by the local branch of Animal Liberation Front, an well known international group of animal rights activists. The wire mesh of the roof was broken into and many animals (approximately 80 ) of $C$. jacchus and $C$. penicillata species were released by the invaders. The invaders left many hostile graffiti, such as Ciência ou hipocre\$ia (Science or hypocre\$ia, sic), Morte aos torturadores!! (Death for the torturers!!), Liberdade aos animais (Freedom to animals),

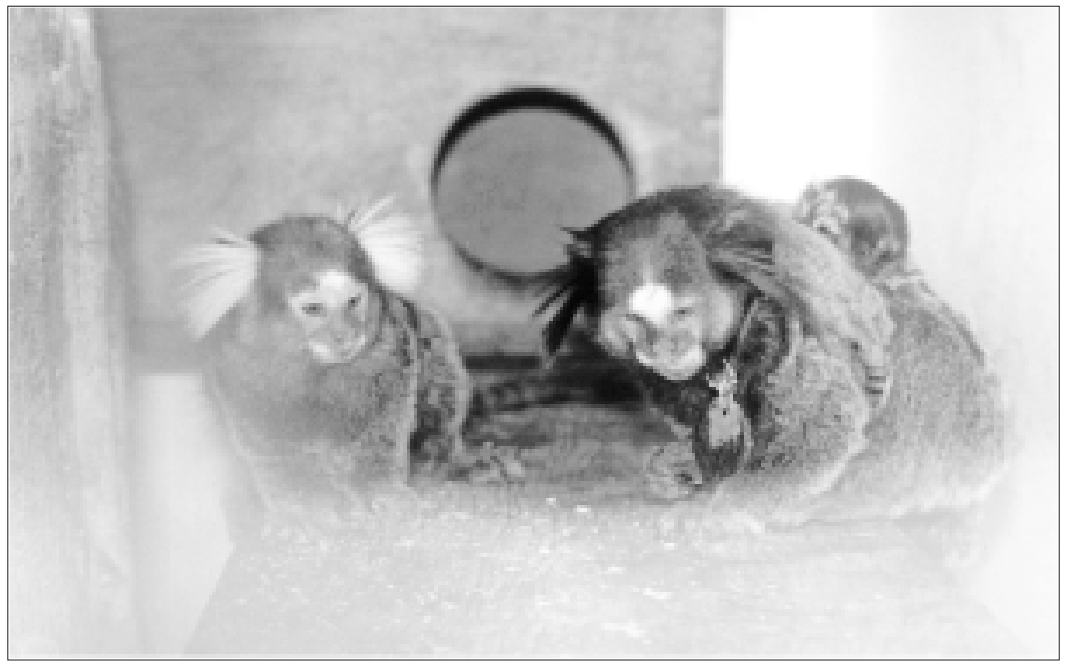

Fig 1 - Cross-fostering in Callitrichids, a black ear-tufted female (C. penicillata, right) is rearing an white ear-tufted infant marmoset $(C$. jacchus, left). In this episode, the female is carrying their 10-day-old twins in the back. 
Pelo respeito à vida (For the respect of life) and others of similar meanings. The Polícia Federal Brasileira was notified about this action and an investigative process was opened in the same day. Thereafter, some posters appeared in the university campus and letters were sent to the Department of Psychology and local press (newspaper and TV). All manifestos contained a clear opposition to use of animal in scientific investigations and the Animal Liberation Front/SC took the responsibility for the invasion, menaces to the researchers and the material damage to the NUCLEP/UFSC.

\section{REFERENCES}

BLERSCH, B. H. \& SCHMIDT, C. R., 1992, Adoption of an additional infant by a Western lowland gorilla (Gorilla gorilla gorilla). Folia Primatol., 58: 190-196.

BOERE, V. \& FERNANDEZ, R. DE L., 1993, Criação artificial e adoção no sagüi comum (Callithrix jacchus): um estudo de caso. A primatologia no Brasil, 4: 289. 304.

DENENBERG, V. H., HUDGENS, G. A. \& ZARROW, M. X., 1964, Mice reared with rats: modification of behavior by early experience with another species. Science, 143: 380-381.

ELLSWORTH, J. A. \& ANDERSEN, C., 1997, Adoption by captive parturient rhesus macaques: Biological vs. Adopted infants and the cost of being a "twin" and rearing "twins". Amer. J. Primatol., 43: 259-264.

FAIRBANKS, L. A., 1990, Reciprocal benefits of allomothering for female vervet monkeys. Anim. Behav., 40: 553-562.

GOULD, L., 1992, Alloparental care in free-ranging Lemur catta at Berenty Reserve, Madagascar. Folia Primatol., 58: 72-83.

GUERRA, R. F., 1989, Infant kidnapping in rhesus monkeys (Macaca mulatta). Ci. Cult., 41(1): 34-38.

HAMILTON, W. J., III, BUSSE, C. \& SMITH, K. S., 1982, Adoption of infant orphan chacma baboons. Anim. Behav., 30: 29-34.

HEARN, J. P. \& BURDEN, F. J., 1979, "Collaborative" rearing of marmoset triplets. Lab. Anim., 13: 131-133.

HRDY, S. B., 1976, Care and exploitation of nonhuman primate infants by conspecifics other than the mother. Adv. Stud. Behav., 6: 101-158.

HUCK, U. W. \& BANKS, E. M., 1980, The effects of cross-fostering on the behavior of two species of North American lemmings, Dicrostonyx groenlandicus and Lemmus trimycronatus. II. Sexual behavior. Anim. Behav., 28: 1053-1062.

JOHNSON, L. D., PETTO, A. J. \& SEHGAL, P. K., 1991, Factors in the rejection and survival of captive cotton top tamarins (Saguinus oedipus). Amer. J. Primatol., 25: 91-102.

LANCASTER, J. B., 1971, Play-mothering: the relations between juvenile females and young infants among free-ranging vervet monkeys (Cercopithecus aethiops). Folia Primatol., 15: 161-182.
LEUTENEGGER, W., 1979, Evolution of litter size in primates. Amer. Natur., 114: 525-531.

McGUIRE, B., 1988, Effects of cross-fostering on parental behavior of meadow voles (Microtus pennsylvanicus). J. Mammal., 69(2): 332-341.

McGUIRE, B. \& Novak, M., 1987, The effects of crossfostering on the development of social preferences in meadow voles (Microtus pennsylvanicus). Behav. Neur. Biol., 47: 167-172.

McKENNA, J. J., 1979, Evolution of allomothering behavior among colobine monkeys: function and opportunism in evolution. Am. Anthropol., 81(4): 818-835.

MEDER, A., 1989, Effects of hand-rearing on the behavioral development of infant and juvenile gorillas (Gorilla $g$. gorilla). Dev. Psychobiol., 22(4): 357-376.

MITTERMEIER, R. A. \& COIMBRA-FILHO, A. F., 1981, Systematics: Species and subspecies. In: A. F. Coimbra-Filho \& R. A. Mittermeier (eds.), Ecology and behavior of neotropical primates, 1: 29-109, Vol. 1. Academia Brasileira de Ciências: Rio de Janeiro.

OWREN, M. J. \& DIETER, J. A., 1989, Infant cross-fostering between Japanese (Macaca fuscata) and rhesus macaques (M. mulatta). Amer. J. Primatol., 18(3): 245-250.

OWREN, M. J., DIETER, J. A., SEYFARTH, R. M. \& CHENEY, D. L., 1993, Vocalizations of rhesus (Macaca mulatta) and Japanese (M. fuscata) macaques crossfostered between species show evidence of only limited modification. Dev. Psychobiol., 26(7): 389-406.

POOK, A. G., 1976, Some notes on the development of hand-reared infants of four species of marmoset (Callitrichidae). The Jersey Wildlife Preservation Trust, $13^{\text {th }}$ Annual Report: 38-48.

QUIATT, D., 1979, Aunts and mothers: adaptive implications of allomaternal behavior of nonhuman primates. Amer. Anthropol., 81: 310-319.

RIEDMAN, M. L., 1982, The evolution of alloparental care and adoption in mammals and birds. Quart. Rev. Biol., 57(4): 405-435.

SHOPLAND, J. M. \& ALTMANN, J., 1987, Fatal intragroup kidnapping in yellow baboons. Amer. J. Primatol., 13: 61-65.

SMITH, S., 1986, Cross-fostering in rhesus monkeys (Macaca mulatta): a procedure for long-term management of captive populations. Amer. J. Primatol., 11: 222-237.

SNOWDON, C. T., 1996, Infant care in cooperatively breeding species. Adv. Study Behav., 25: 643-689.

THIERRY, B. \& ANDERSON, J. R., 1986, Adoption in anthropoid primates. Int. J. Primatol., 7: 191-216.

WOLFE, L. G., OGDEN, J. D., DEINHARDT, J. B., FISHER, L. \& DEINHARDT, F., 1972, Breeding and hand-rearing marmosets for viral oncogenesis studies. In: W. I. B Beveridge (ed.), Breeding primates, pp. 145157, S. Karger: Basel. 